\title{
Shale Gas Potential in Telisa Formation, Central Sumatera Basin as a Review to Fulfill Future Energy Demand
}

\author{
Karina Meninta ${ }^{\mathrm{a}}{ }$, Muhammad Tressna Gandapradana $^{\mathrm{a}}$, Dicky Muslim ${ }^{\mathrm{b}}$ \\ ${ }^{a}$ Himpunan Mahasiswa Geologi, Universitas Padjadjaran Jl. Raya Bandung -Sumedang Km. 21 Jatinangor 45363, Indonesia \\ ${ }^{b}$ Faculty of Geology, Universitas Padjadjaran Jl. Raya Bandung -Sumedang Km. 21 Jatinangor 45363, Indonesia
}

\begin{abstract}
These days, world's energy demand is increasing because of so many factors and at the same time conventional energy resource was decreasing for a last few years. In this situation, shale gas rise and rapidly growth to fulfill world's energy demand. Shale gas is a natural gas which is trapped within the shale formation because of shale impermeable characteristic. Shale refers to fine grained, laminated, clastic sedimentary rocks that can be rich of organic matters. Focus study in this research is located in Telisa rock formation, Central Sumatera. This research methods used literature study concerning in regional geology including regional stratigraphy, structural geology and geochemistry analysis. Telisa formation has a great potential of shale gas resource. Therefore, it is interesting to discuss about Telisa formation potential of shale gas to alternate conventional energy to fulfill future energy demand.
\end{abstract}

Keywords: energy demand; geochemistry; shale gas; telisa formation; unconventional energy

$\begin{array}{ll}\text { Nomenclature } & \\ \text { MBOPD } & \text { milion barrel oil per day } \\ \text { TCF } & \text { trillion cubic feet } \\ \text { TOC } & \text { total organic carbon } \\ \text { HI } & \text { hydrogen index } \\ \text { OI } & \text { oxygen index } \\ \text { mgHC } & \text { milligram hydrocarbon } \\ \text { CBM } & \text { coal bed methane }\end{array}$

\section{Introduction}

The need of energy resources is always increasing every year. This increase is related to the number of population growth, regional development, industry needs and other human activities that use energy. Until now, fossil fuels such as petroleum and natural gas is still widely used by public more than other energy resource.

Problems arise when this energy resource production began to decline over time. Oil and natural gas is a non renewable energy so that it will run out if it has been exploited. In this condition, oil and natural gas need to be producted more especially new energy resources as a future energy reserves [1]. 
Energy consumption is always increasing with energy production is always decreasing. In Indonesia, this curve has met in 2003 when the consumption number higher than the production and need to import energy resources from other country. This phenomenon was getting worse from year to year and in 2010 Indonesia need 1600 MBOPD while Indonesia just can produce 1050 MBOPD based on EIA International Energy Statistics [2]. It conclude that Indonesia need $550 \mathrm{MBOPD}$ energy more and import this deficit from other country. It become problems because it can reduce our foreign exchange.

In this condition, shale gas appeared to be a solution as unconventional energy to replace conventional oil and natural gas which are used lately. Focus study in this research is located in Telisa Formation, Central Sumatera as a source of shale gas. Shale gas is a natural gas which is trapped within the shale formation because of shale impermeable characteristic. Shale refers to fine grained, laminated, clastic sedimentary rocks that can be rich of organic matters. Shale gas must be learned and searched more to replace conventional energy and fulfill future energy demand.

\section{Material and methods}

This research used several data material such as regional geology map, and secondary data from previous research both institutional or non-institutional. Methodology used in this research such as basin analysis and geochemistry analysis. Basin analysis including structural analysis, stratigraphic analysis, and basin evolution.

\section{Result and discussion}

Subduction between oceanic crust in Indo Australian plate and continental plate of Eurasian plate result a flexure which becomes volcanic arc. The fore side and back side of this volcanic arc formed a sedimentary basin. Central Sumatera Basin was one of back arc basin in Sumatera. This basin trend is relatively longwise from Northwest to SouthEast.

This basin is adjacent with Sunda Craton in Northeast, Barisan Mountain which is composed of Pre-tertiary rocks in Southwest, Asahan Arc in the Northwest which separate this basin with North Sumatera Basin, and Tigapuluh mountain in Southeast which separate this basin with South Sumatera Basin.

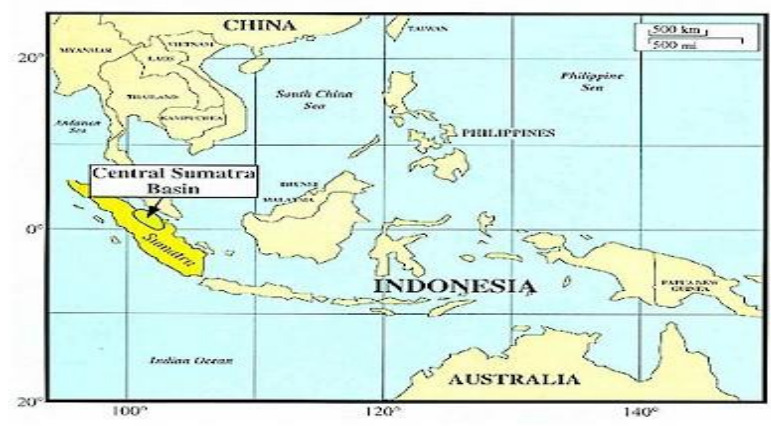

Fig. 1. Location of Central Sumatera basin.

Regional structural of Central Sumatera Basin has a similar structural pattern with South Sumatera Basin where the main pattern developed has Northwest-Southeast trend and the dominant is North-South trend. Structural of Central Sumatera basin was influenced by Sumatera fault which is formed in Cretaceous. Several phenomenons such as steeply fault plane along the rock beddings, reverse fault, and the presence of flower structure formed when tectonic inversion is the result of plate subduction from the southwest of the Sumatera which also cause strong dextral wrenching stress in Central Sumatera [3]. 
Tectonic and Stratigraphy of Central Sumatera Basin affected by three major phase [3]. These three phase is :

- Pre-Rift Phase

Consist of Pre-tertiary sedimentary rocks. This basement orientation is NorthWest-SouthEast. Existing structure is generally a fault which have been experiencing a reactivation into reverse fault and transform fault. These fault is also be a boundary of the existing basement terranes. (from East to West, Malacca, Mutus, Mergui and Kualu

- $\quad$ Syn-Rift Phase

Rift formation in the early Eocene - Late Oligocene that filled by sediment of Pematang Group which consist of 3 formation : Lower Red Bed, Brown Shale dan Upper Red Bed, approximately ranging from $50-25.5$ Million years ago.

- $\quad$ Post-Rift Phase

In this phase, sagging has occurred in Central Sumatera Basin and caused sea level to inundate this basin. Sediment from this phase is Sihapas Group which consist of Menggala formation, Bangko formation, Bekasap formation, Duri formation and Telisa formation.

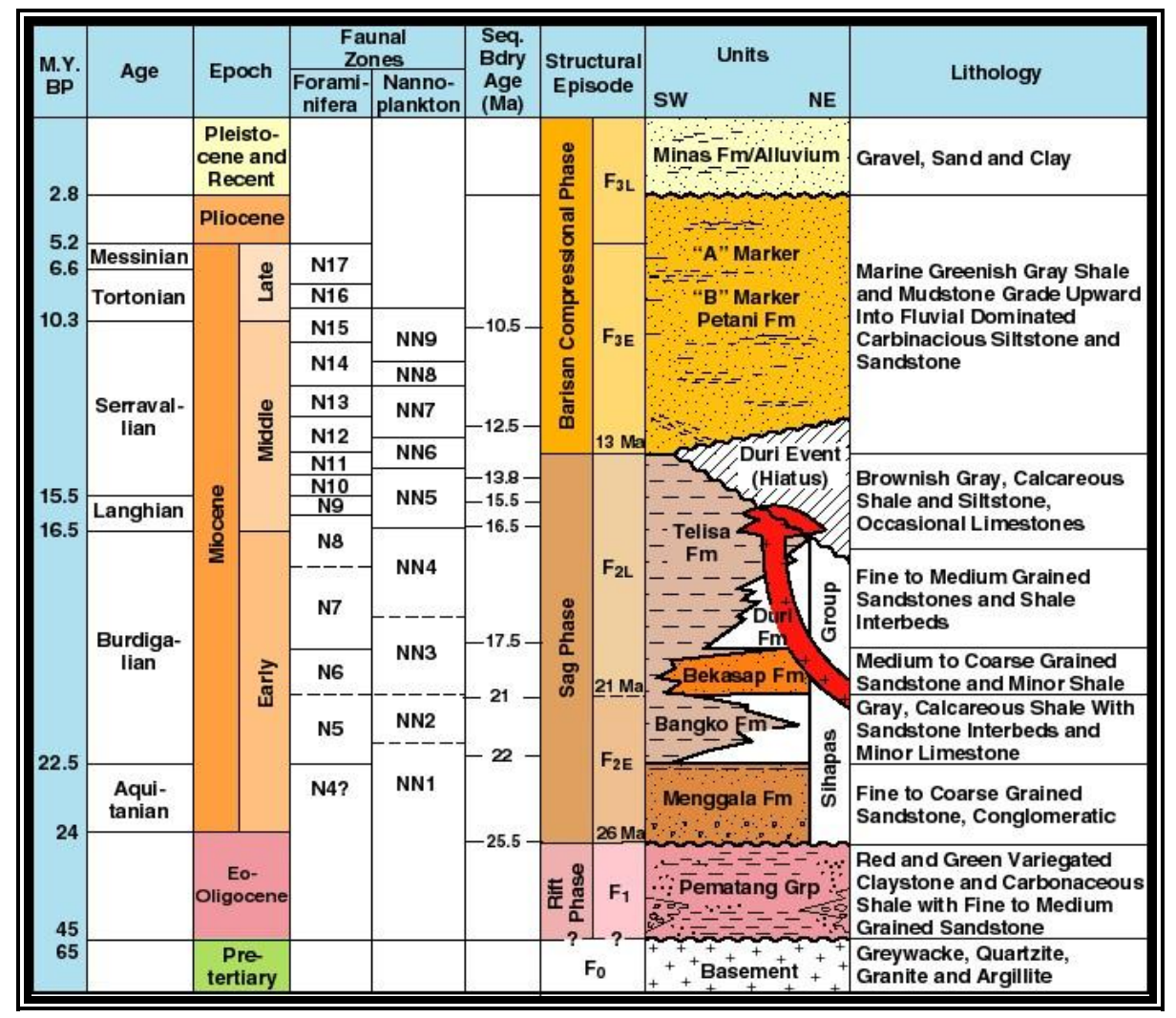

Fig. 2. Stratigraphic column of Central Sumatera basin with tectonic phase [4].

Sedimentation process in Central Sumatera Basin began in the early Tertiary (Paleogene), following the formation of the half graben basin that has been going on since Cretaceous to Early Tertiary. Generally, the order of the formation in Central Sumatera Basin from the oldest to the youngest is : 


\section{- Pematang Group.}

This group is the oldest sedimentary Eocene-Oligocene which deposited unconformably above the basement. This group deposited in fluvial and lacustrine environment. Organic shales of the Pematang group is a source rock for hydrocarbon in Central Sumatera Basin. This group consist of Lower Red Bed formation, Brown Shale formation, and Upper Red Bed formation.

\section{- Sihapas Group}

Sihapas group was deposited above the Pematang group, it is a sedimentary series at the time of tectonic activity began to decrease, occurred during the Late Oligocene to Middle Miocene. This period was followed by a resubsidence and transgression into the basin. This group consist of Menggala formation, Bangko formation, Bekasap formation, Duri formation dan Telisa formation. Further source potential exists within the marine Telisa Formation of the Sihapas Group. The units contains a dominance of gas-prone kerogens [5]. Beside of kerogen, Telisa Source rock has (5 to 5000$) \mathrm{mg} / \mathrm{l}$ indigeneous hydrocarbon. Migrated hydrocarbons is just small fraction than indigeneous hydrocarbon [6]

Shale gas is a natural gas which is trapped within shale formation because of shale impermeable characteristic. As we know, shale is lack of permeability so the hydrocarbon generated in it cannot migrate to other formation. To get the hydrocarbon, we require fracture or secondary porosity by natural or artificial action. With horizontal drilling and hydraulic fracturing we can make fracture in shale formation and the gas flows into the pipe and up the well. It is unique when shale as a source rock become reservoir too in shale gas play [7].

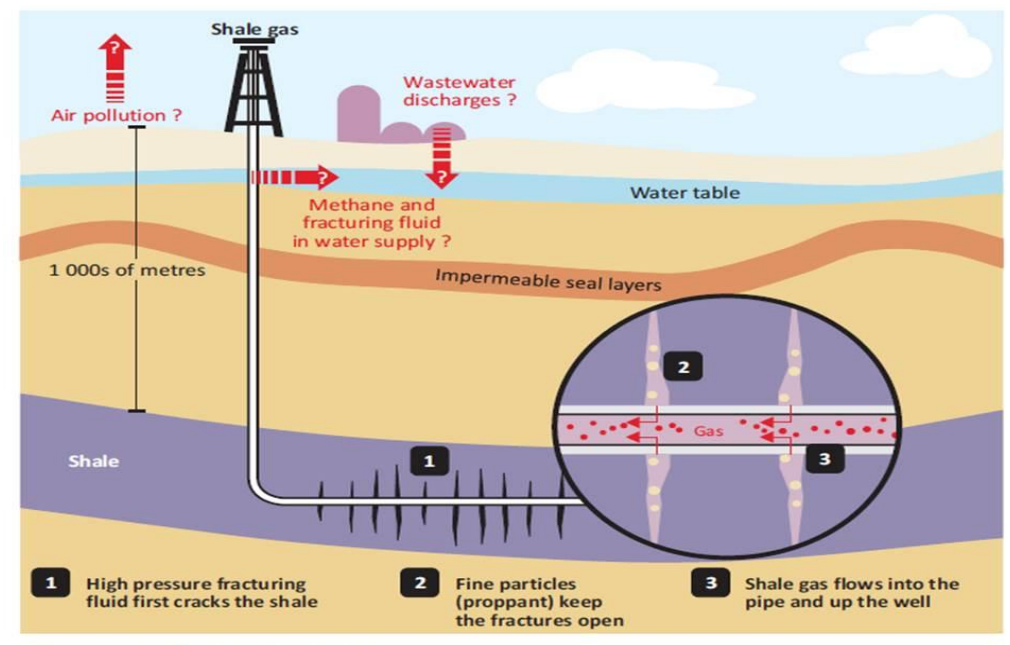

Source: Adapted from Aldhous (2012).

Fig. 3. Shale gas exploitation [7].

Shale gas potential is quite large in Indonesia about 574 trillion cubic feet (TCF). Shale gas reserves in Indonesia is greater than Coal Bed Methane about 453.3 TCF and natural gas about 334.5 TCF [8]. 
Table 1. Speculative resources of shale gas in Indonesia [8].

\begin{tabular}{|c|c|c|c|c|}
\hline No. & Region & Basin & $\begin{array}{l}\text { Volume of gas } \\
\text { in place (TCF) }\end{array}$ & $\begin{array}{l}\text { Total volume of } \\
\text { gas in place (TCF) }\end{array}$ \\
\hline \multirow{4}{*}{1} & \multirow{4}{*}{ Sumatera } & North Sumatera & 64.78 & \multirow{4}{*}{$233, .05$} \\
\hline & & Central Sumatera & 86.90 & \\
\hline & & Ombilin & 25.26 & \\
\hline & & South Sumatera & 56.11 & \\
\hline \multirow[t]{2}{*}{2} & \multirow[t]{2}{*}{ Java } & Northwest Java & 5.64 & \multirow[t]{2}{*}{47.64} \\
\hline & & Northeast Java & 42 & \\
\hline \multirow{5}{*}{3} & \multirow{5}{*}{ Borneo } & Barito & 74.59 & \multirow{5}{*}{193.93} \\
\hline & & Kutei & 80.59 & \\
\hline & & Tarakan & 7.22 & \\
\hline & & Melawi & 11.9 & \\
\hline & & Ketungau & 19.63 & \\
\hline 4 & Sulawesi & Sengkang & 5.41 & 5.41 \\
\hline \multirow[t]{3}{*}{5} & \multirow[t]{2}{*}{ Papua } & Akimeugah & 62.64 & \multirow[t]{2}{*}{94.04} \\
\hline & & Bintuni & 31.40 & \\
\hline & \multicolumn{3}{|c|}{ Total speculative resources of shale gas } & 574.07 \\
\hline
\end{tabular}

The advantages of shale gas is shale gas produces carbon emissions significantly less than coal. Large shale gas production can help improve energy security and reduce dependence on fossil fuels. The cost of shale gas extraction is higher than the cost of coal or conventional gas extraction, with advances in drilling technology can help reduce the cost of extracting shale gas as future energy [7].

Based on geochemical analysis, organic matter rich and mature shale can produce oil and gas due to capillary pressure and loading so we can eject that oil and gas out to the surface. Oil and gas migrate and driven to higher ground can be exploit further. According to experts, only $10 \%$ of oil and gas that can migrate, whereas $90 \%$ of oil and gas produced is stored in the hostrock which we refer to shale gas or shale oil [8].

Based on geomechanics, shale has small pores only (2 to 5 ) \% so that we require a secondary porosity by cracking the rocks. Through geomechanics study we can know that character of shale is quite brittle or not to be crack. Brittle nature is very important to form open path or stream to the gas inside the pores when we do fracturing.

Organic content is usually associated with shales or silty shales, and is an indicator of potential hydrocarbon source rocks. High resistivity with some apparent porosity on a log analysis is a good indicator of organic content. Kerogen is the main source of TOC; kerogen is usually radioactive (uranium salts) and gas shales with significant adsorbed gas are often very radioactive (> 150 API units).

Focus study in this research is located in Telisa Formation as a source of shale gas. Regionally, marine shales of this formation has the same age with Sihapas group, making contact with the underlying Telisa formation is different lithological transitions in the stratigraphic position and place. Thickness of this formation reaches $550 \mathrm{~m}$. From fossil analysis, this formation age is range from N6 until N11. 
Telisa formation which represent episodes of sedimentation during transgression peak is composed of shale with little intercalation smoother sandstone at the bottom. In some places there are limestone lenses at the bottom of formation. Towards the top, the formation turn into shale characterize the environment to the deeper zone. Depositional environment is interpreted between Neritic - Bathyal.

The shale deposit is rich in organic matter, shown by the TOC (total organic carbon) content that ranges from (3.13 to 14.80$) \%$ [9]. With this TOC, telisa shale richness considered as very good - excellent [9].

Table. 2. Geochemical parameters describing the petroleum potential of source rock [10].

\begin{tabular}{|c|c|c|c|c|c|c|}
\hline \multirow{3}{*}{$\begin{array}{c}\text { Petroleum } \\
\text { Potential }\end{array}$} & \multicolumn{3}{|c|}{ Organic Matters } & \multirow{2}{*}{\multicolumn{2}{|c|}{ Bitumen $^{c}$}} & \multirow{3}{*}{$\begin{array}{l}\text { Hydrocarbons } \\
(\mathrm{mg} / \mathrm{g})\end{array}$} \\
\hline & \multirow{2}{*}{$\begin{array}{l}\text { TOC } \\
(\%)\end{array}$} & \multicolumn{2}{|c|}{ Rock-Eval Pyrolisis } & & & \\
\hline & & $\mathrm{S}^{\mathrm{a}}$ & $\mathrm{S} 2^{\mathrm{b}}$ & $(\%)$ & $(\mathrm{mg} / \mathrm{g})$ & \\
\hline Poor & 0 to 0.5 & 0 to 0.5 & 0 to 0.25 & 0 to 0.05 & 0 to 500 & 0 to 300 \\
\hline Fair & 0.5 to 1 & 0.5 to 1 & 2.5 to 5 & 0.05 to 0.10 & 500 to 1000 & 300 to 600 \\
\hline Good & 1 to 2 & 1 to 2 & 5 to 10 & 0.10 to 0.20 & 1000 to 2000 & 600 to 1200 \\
\hline Very Good & 2 to 4 & 2 to 4 & 10 to 20 & 0.20 to 0.40 & 2000 to 4000 & 1200 to 2400 \\
\hline Excellent & $>4$ & $>4$ & $>20$ & $>0.40$ & $>4000$ & $>2400$ \\
\hline
\end{tabular}

${ }^{\mathrm{a}} \mathrm{mgHC} / \mathrm{g}$ dry rock distilled by pyrolisis

${ }^{\mathrm{b}} \mathrm{mgHC} / \mathrm{g}$ dry rock cracked from kerogen by pyrolisis

${ }^{c}$ Evaporation of the solvent used to extract bitumen from a source rock or oil from a reservoir rock causes loss of the volatile hydrocarbons below about $n-C_{15}$.

Based Rock-eval pyrolisis analysis on a number of selected samples, HI versus OI diagram shows that organic matter is categorized as oil/gas prone-type II kerogen where alginite and liptinite are the dominant lithology. Plot TOC against $(\mathrm{S} 1+\mathrm{S} 2)$ indicates that the source rock in the study area has a good - excellent gas generation potential [11].

Table 3. Kerogen type character [12].

\begin{tabular}{|l|l|l|l|}
\hline Kerogen Type : & Type I (Algal) & Type II (Liptinic) & Type III (Humic) \\
\hline Kerogen Source : & Marine algae and plankton & $\begin{array}{l}\text { Marine and terrestrial plant and } \\
\text { animal material }\end{array}$ & Terrestrial plant material \\
\hline Hydrogen to Carbon ratio & $>1.25$ & $<1.25$ & $<1.0$ \\
\hline Oxygen to Carbon ratio & $<0.15$ & 0.03 to 0.18 & 0.03 to 0.3 \\
\hline $\begin{array}{l}\text { Hydrocarbon formation } \\
\text { propensity }\end{array}$ & $\begin{array}{l}\text { Rich in hydrogen and poor in } \\
\text { oxygen and thus tends to } \\
\text { produce liquid oil }\end{array}$ & Produce liquid oil and/or gas & $\begin{array}{l}\text { Low in hydrogen and high in } \\
\text { carbon so produces mainly coal }\end{array}$ \\
\hline
\end{tabular}




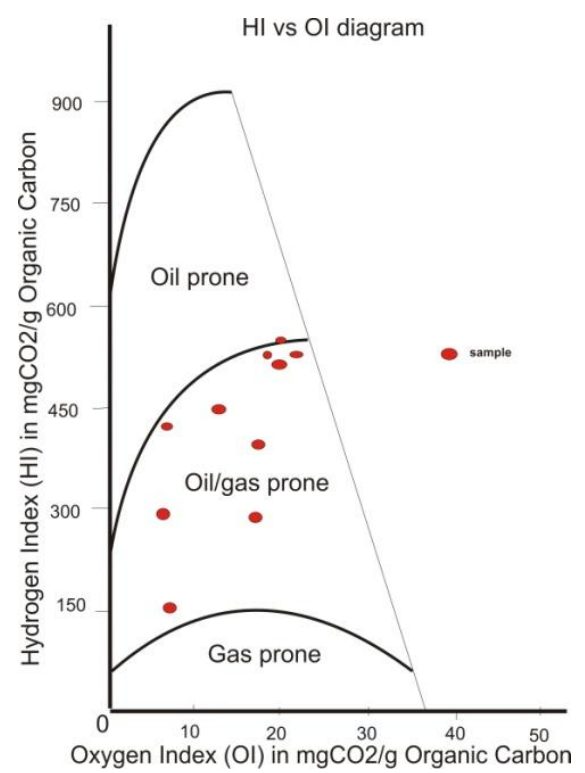

Fig. 4. Plotting of Hydrogen Index and Oxygen Index in Telisa formation [13].

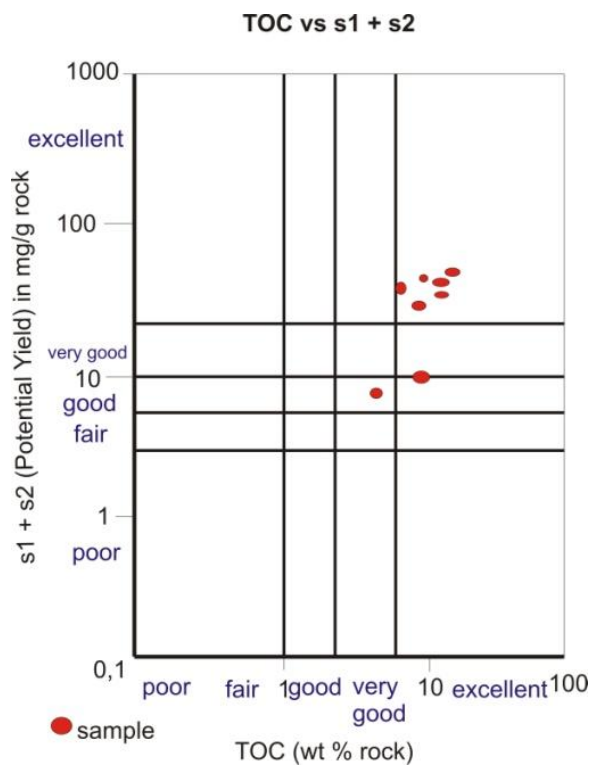

Fig.5. Correlation between Total Organic carbon (TOC) with $\mathrm{S} 1+\mathrm{S} 2$ potential yield [13].

Shale gas has the opportunities to maximize our energy resources. High potential of shale gas can be used to fulfill future energy demand and be a solution for energy production decreasing in Indonesia. Estimated shale gas resource is more than other resource reached 574 TCF in Indonesia, compare to Coal Bed Methane that has 453,3 TCF and natural gas that has 334,5 TCF. Moreover, shale gas has lower carbon emission than other resource such as coal and CBM [11]. The challenge can be an obstacle for shale gas are as follows : 
- Investments are quite expensive to technology development. The costs incurred to develop unconventional methods is more expensive than the conventional method.

- Exploration technology and production of unconventional gas is more difficult than conventional gas

- Mechanical drilling with hydraulic fracturing methods must be environmentally friendly

- Basis law and local government should support the development of unconventional gas

- Geographical conditions need to be minimized with adequate infrastructure

- Efficient using of unconventional gas so that reserves are not depleted drastically

\section{Conclusion}

Shale gas has a great potential to replace conventional energy for several decade ahead. One of shale gas potential in Indonesia is located in Telisa formation, Central Sumatera Basin. Central Sumatera Basin has experienced three phase of tectonics. In Pre Rift, there lied basement rocks. In Syn rift, deposited Pematang Group and Sihapas Group deposited in Post rift. Telisa formation is one of Sihapas Group. This formation deposited in Neritic - Bathyal environment, deposited during transgression peak, composed of shale with little intercalation smoother sandstone at the bottom, and limestone lenses at the bottom of formation and shale towards the top of the formation.

TOC (total organic carbon) content of shale deposit in Telisa ranges from $3.13 \%$ to $14.80 \%$. With this TOC, telisa shale richness considered as very good - excellent. Based Rock-eval pyrolisis analysis, HI versus OI diagram shows that organic matter is categorized as oil/gas prone-type II kerogen where alginite and liptinite are the dominant lithology. Plot TOC against $(\mathrm{S} 1+\mathrm{S} 2)$ indicates that the source rock in the study area has a good - excellent gas generation potential.

\section{Acknowledgements}

The Authors are thankful to all previous researchers. Thank you to Universitas Padjadjaran and HMG that have support with morally and materially to write this paper.

\section{References}

[1] International Energy Agency. Golden rules for a golden age of gas. Jakarta; 2012.

[2] Astalavista. Indonesia energy report; 2011. Accessed on May $15^{\text {th }}, 2014$ from http://www.endofcrudeoil.com /2011/12/indonesia-energy-report.html.

[3] Heidrich, Aulia. Regional structural geology. Chapter II; 1996.

[4] Eubank RT, Makki AC. Structural geology of the Central Sumatra Back Arc Basin. In: Proceeding Indonesian Petroleum Association, $10^{\text {th }}$ Annual Convention. Jakarta; 1981.

[5] Patra Nusa Data. Indonesia Basin Summaries; 2006

[6] Phillipi GT, Identification of Oil Source Beds by Chemical Means, $20^{\text {th }}$ International Geological Conference Proceeding, Mexico ; 1957

[7] Aldhous P. Drilling into the unknown. New Scientist 2012; Issue 2849. p. 8-10.

[8] Pusat Data dan Informasi ESDM. Indonesia energy outlook 2010. Jakarta; 2010. [Bahasa Indonesia]

[9] Sukhyar. Unconventional oil and gas potential in Indonesia with special attention to shale gas and coal-bed methane. Jakarta; 2013.

[10] Kevin MKR, Martin N, Daniel P, Kenneth P, Artur S. Basic Petroleum Geochemistry for Source Rock Evaluation. Schlumberger; 2011.

[11] Peters KE, Cassa MR. Applied source rock geochemistry. AAPG Memoir 60; 1994.

[12] National Energy Board of Canada. A primer for understanding Canadian shale gas; 2009

[13] Tobing SM. Potensi kandungan minyak dalam bitumen padat, daerah Padanglawas, Sumatera Barat. Bandung: PSDG; 2007. [Bahasa Indonesia]

[14] Crain ER. Shale gas basics. Accessed on May 15 ${ }^{\text {th }}, 2014$ from : http://spec2000.net/17-specshgas.htm; n.d 